\title{
A Rising Plate Meter for Estimating Production and Utilization
}

\author{
JERRY H. SCRIVNER, D. MICHAEL CENTER, AND MILTON B. JONES
}

\section{Abstract}

The rising plate meter (RPM) was used to determine forage production and livestock utilization in a rotational graxing system on improved annual pasture in Callfornia. Prior to rotating livestock, herbage weight (y) was related to meter reading (x) by the linear model: $y=a+b x$. Forage utilization by sheep was estimated by summing growth and disappearance in grazed pastures. Forage disappearance for pastures was based on meter readings before and after grazing. Plant growth in grazed pastures for the same period was based on meter readings for pastures not then grazed. Use of RPM in a rotational grazing system proved to be a quick and effective way of assessing forage growth and utilization.

In grazing studies, it is often desirable to have estimates of both forage production and its utilization by livestock. A common method of assessing production and utilization is to protect small areas from grazing with exclosures. Difference in production between grazed and ungrazed samples at the end of each grazing period is a measure of forage utilization. A problem with this technique is that cages have an influence on herbage yields (Grelen 1967, Owensby 1969). Cowlishaw (1951) and Daubenmire (1940) have attributed the yield differences to differences in microclimate, i.e., temperature, humidity, rainfall, and wind.

Authors are postgraduate researchers and agronomist, respectively, Department of Agronomy and Range Science, University of California, Hopland Field Station, Hopland 95449.

Manuscript accepted 4 April 1986.
Also, depending upon ecological conditions, grazed plants may produce more or less than protected plants (Cook and Stoddart 1953, Jones 1967). Generally, the smaller the period of time between caging and clipping, the smaller the difference in growth on protected and grazed areas (Joint Committee 1962).

Recently, a semiautomatic rising plate meter (RPM) was used to estimate yields on irrigated pasture grazed by dairy cows in Australia (Stockdale 1984). The RPM estimated pregrazing yield more precisely than a visual assessment. The 2 techniques were similar for estimating postgrazing yields.

Earle and McGowan (1979) found the RPM to be advantageous over other measuring methods in that its semiautomatic function permits up to 100 measurements to be made in 5 minutes. They found no significant differences in accuracy between a manual rising plate meter and a two-probe electronic capacitance meter. The electronic meter is relatively insensitive to the presence of dry forage and provides an estimate when plants are physiologically active (Neal et al. 1976). The plate measures a combination of dead and green forage. Therefore it is more effectively used to estimate total standing crop where there is a mixture of dead and green forage.

The purpose of this study was to assess the feasibility of using the RPM on improved annual pasture in California to determine forage production and livestock utilization in a rotational grazing 
system. This paper discusses advantages, limitations, and methods of the technique.

\section{Methods}

Data were gathered at the University of California Hopland Field Station on studies assessing the effects of sulfur fertilization on pastures seeded to subterranean clover (Trifolium subterraneum L.), and Italian ryegrass (Lolium multiflorum L.) and on livestock grazing the fertilized pastures. In one study, 1 flock of yearling ewes was rotated between 2 unfertilized clover pastures and another flock between 2 fertilized clover pastures. In a second study, 1 flock of yearling ewes was rotated between 2 unfertilized ryegrass pastures and another flock between 3 fertilized ryegrass pastures.

The RPM is used by holding onto a handle at one end of a shaft and resting the other end of the shaft on the ground. Forage prevents a plate from dropping to the ground. A measure of forage height is recorded on a counter attached to the shaft.

Prior to introducing sheep onto the pastures, and at regular intervals throughout the studies, meter readings were taken on 4 to twelve $0.09-\mathrm{m}^{2}$ quadrats per pasture representing a range of pasture yields. Herbage was hand-clipped to ground level from the same quadrates, dried at $65^{\circ} \mathrm{C}$ for 48 hours, then weighed. Herbage weight $(y)$ in $\mathrm{kg} /$ ha was related to meter reading $(x)$ by the linear model: $\mathbf{y}=\mathbf{a}+\mathbf{b x}$.

For each study, and at each of 5 dates, regression coefficients (intercepts and slopes) of calibration equations for fertilized and unfertilized pastures, and grazed and ungrazed pastures were statistically compared to determine if calibration data consisted of distinct subsets, each of which requiring a separate regression equation, or if one regression relationship could be used to represent the pooled data set (Chatterjee and Price 1977). When parameter estimates were significantly different $(P<0.05)$, separate equations were used to estimate herbage yield; otherwise, the data were pooled and 1 regression equation used.

Once calibration equations were developed, and prior to rotating sheep, 150 meter readings per pasture were taken along 3 transects in each pasture. Herbage yield per pasture was estimated based on the average meter reading per pasture. In pastures in which sheep were present, forage disappearance was calculated based on meter readings before and after grazing. Forage growth in grazed pastures was calculated from meter readings taken from ungrazed pastures during the same period. Livestock utilization was calculated by adding growth in pastures not then grazed to disappearance measured in grazed pastures.

Total season growth for pastures in which sheep were rotated was estimated by summing the product of pasture size (ha) and growth $(\mathrm{kg} / \mathrm{ha})$ for all pastures and grazing periods. Forage disappearance $(\mathrm{kg})$ was calculated by summing the product of pasture size (ha) of grazed pasture and disappearance ( $\mathrm{kg} / \mathrm{ha}$ ) for all grazing periods. The relationship of forage production, utilization, and beginning and ending standing crop is: $\mathrm{SC}_{\mathrm{a}}=\mathrm{SC}_{\mathrm{b}}+\mathrm{G}-\mathrm{U}$, where $\mathrm{SC}_{\mathrm{e}}=$ standing crop at the end of the study, $\mathrm{SC}_{\mathrm{b}}=$ standing crop at the beginning of the study, $G=$ total season growth, and $U=$ total forage utilized.

\section{Results and Discussion}

\section{Subclover}

The relationship for herbage weight and meter reading for the 5 plate-calibration dates is illustrated in Figure 1. Most regression equations for unfertilized and fertilized pastures and grazed and ungrazed pastures for a given date were similar; thus, a single calibration equation combining data from all pastures were used to estimate standing crop at each calibration date. The regression equations for the 3 March yield estimates on the grazed and ungrazed clover pastures differed significantly. Therefore separate equations were used to estimate standing crop until the 25 April calibration date.

For all clover pastures and grazing periods, standard errors for

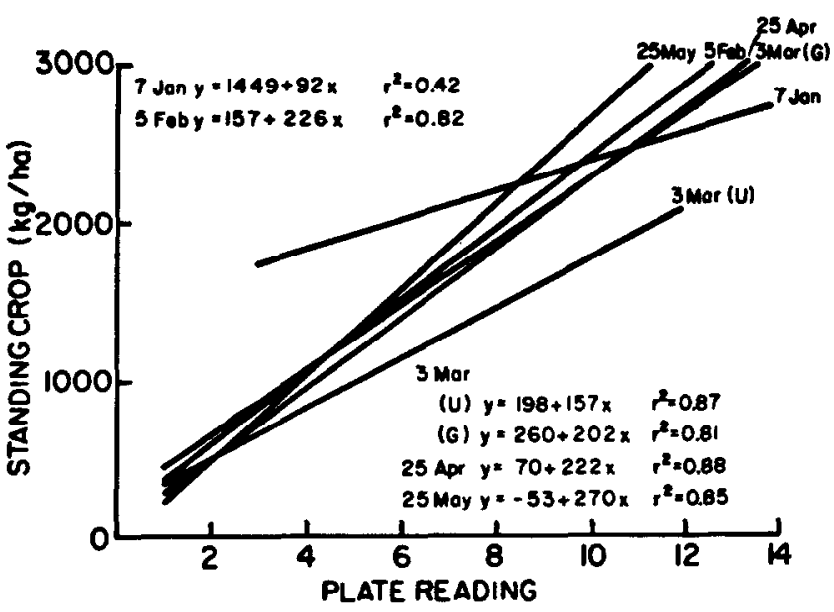

Fig. 1. The relationship between subclover herbage weight (y) in $\mathrm{kg} / \mathrm{ha}$ to meter reading $(x)$ using the linear model $y=a+b x$. " $G$ " and " $U$ " refer to "grazed" and "ungrazed", respectively. All linear relationships were statistically significant $(\mathbf{P}<0.05)$.

predicted yield estimates averaged $105 \pm 28 \mathrm{~kg} / \mathrm{ha}(\bar{x} \pm \mathrm{SD})$. Ninety percent confidence intervals of yield estimates averaged 176 $\pm 46 \mathrm{~kg} / \mathrm{ha}$. This was a mean of $17 \pm 9 \%$ of yield estimates.

Regression coefficients of each calibration equation were statistically compared (Chatterjee and Price 1977) to regression coefficients of calibration equations for the following date to evaluate the necessity of recalibrating the RPM. In all instances, equations for different dates were significantly different. This difference was greatest for the 7 January and 5 February comparison. Since average meter readings on 5 February for the four subclover pastures ranged from 2.9 to 6.6 , using the 7 January model for estimating standing crop on 5 February would have resulted in overestimating forage yield by about 400 to $900 \mathrm{~kg} / \mathrm{ha}$.

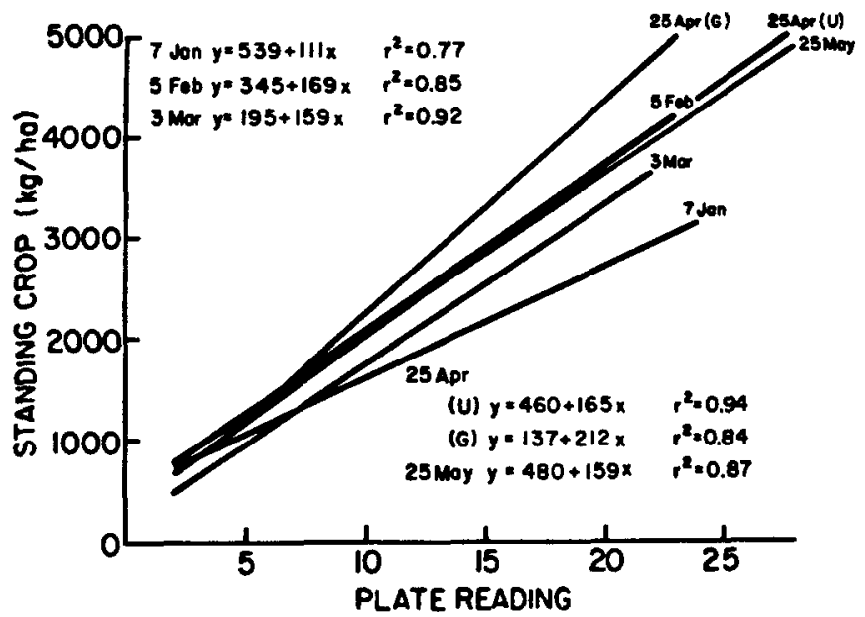

Fig. 2. The relationship between ryegrass herbage weight $(y)$ in $\mathrm{kg} / \mathrm{ha}$ to meter reading $(x)$ using the linear model $y=a+b x$. " $G$ " and " $U$ " refer to "grazed" and "ungrazed", respectively. All linear relationships were statistically significant $(\mathbf{P}<0.05)$.

\section{Ryegrass}

With one exception, regression equations for unfertilized and fertilized and grazed and ungrazed pastures for a given date were similar. Therefore a single calibration equation combining data from all pastures was used to estimate standing crop at each sampling date (Fig. 2). On 25 April, the grazed and ungrazed ryegrass pastures differed significantly; thus, separate equations were used to estimate standing crop until the 25 May calibration.

For all ryegrass pastures and grazing periods, standard errors for predicted yield estimates averaged $137 \pm 92 \mathrm{~kg} / \mathrm{ha}$. Ninety percent confidence intervals of yield estimates averaged $239 \pm 168 \mathrm{~kg} /$ ha which was a mean of $12 \pm 9 \%$ of yield estimates. 
As in the clover study, calibration equations for different dates were significantly different. These differences were also greatest for the 7 January and 5 February comparison. Since average meter readings for the 5 ryegrass pastures on 5 February ranged from 6.7 to 10.8 , standing crop on 5 February would have been underestimated by about 200 to $450 \mathrm{~kg}$ / ha had the 7 January equation been used.

In general, use of the RPM in a rotational grazing system proved to be a quick and effective way of assessing total forage growth and utilization. The method was assumed as comparable to clipping inside and outside cages moved at regular intervals. The RPM is simple to operate, lightweight, and durable, and is a relatively nondestructive method of assessing forage production. To obtain reliable results, however, several factors regarding application of the technique must be kept in mind. Rate of growth in ungrazed pastures is assumed to equal the rate of growth in grazed pastures. This assumption is probably most often satisfied when grazing periods are short and pastures are ecologically similar.

Calibration equations were also obtained often enough to account for phenological changes. The effect of treatment application never resulted in significantly different calibration equations and the impact of grazing was significant at only 2 dates. Thus, the relationship of herbage weight to RPM reading may or may not change as sheep graze previously ungrazed pastures, as treated pastures respond to fertilizer application, and as forage matures and stiffens as the season progresses. If calibration equations differ as a result of any of the above causes, then separate equations should be used to estimate herbage phytomass. Since it is usually not known if any of these variables have changed since earlier calibrations, it is generally best to calibrate often (at least monthly).
Care should be taken to minimize sample bias when taking plate readings. Unusually stiff-leaved plants, irregular terrain, small pebbles, and even livestock feces may bias plate readings and lead to inaccurate forage-production estimates. Most of these influence forage estimates more when the amount of forage is low and patchy. Thus, in annual systems, production estimates are most subject to error early and late in the season. Early season estimates may particularly be influenced by dry residual material from the preceeding growing season.

\section{Literature Cited}

Chatterjee, S., and B. Price. 1977. Regression analysis by example. John Wiley and Sons, New York.

Cook, C.W., and L.A. Stoddart. 1953. The quandary of utilization and preference. J. Range Manage. 6:329-335.

Cowlishaw, S.J. 1951. The effect of sampling cages on the yields of herbage. J. Brit. Grassl. Soc. 6:179-182.

Daubenmire, R.F. 1940. Exclosure technique in ecology. Ecology 21:514-515.

Earle, D.F., and A.A. McGowan. 1979. Evaluation and calibration of an automated rising plate meter for estimating dry matter yield of pasture. Aust. J. Exp. Agr. Anim. Husb. 19:337-343.

Grelen, H.E. 1967. Comparison of cage methods for determining utilization on pine-bluestem range. J. Range Manage. 20:94-96.

Joint Committee-American Society of Range Management and Agricultural Board of the National Research Council. 1962. Basic problems and techniques in range research. Nat. Acad. Sci.-Nat. Res. Counc. Pub. 890, Washington, D.C.

Jones, M.B. 1967. Forage and protein production by subclover-grass and nitrogen fertilized California grasslands. California Agr. 21:4-7.

Neal, D.L., P.O. Currie, and M.J. Morris. 1976. Sampling herbaceous native vegetation with an electronic capacitance instrument. J. Range Manage. 29:74-77.

Owensby, C.E. 1969. Effect of cages on herbage yield in true prairie vegetation. J. Range Manage. 22:131-132.

Stockdale, C.R. 1984. Evaluation of techniques for estimating the yield of irrigated pastures intensively grazed by dairy cows. 2 . The rising plate meter. Aust. J. Agr. Anim. Husb. 24:305-311. 